J. Clin. Chem. Clin. Biochem.

Vol. 17, 1979, pp. 111-114

\title{
A Rapid and Specific Method for Separation of Bound and Free Antigen in Radioimmunoassay Systems
}

By W. G. Wood, G. Stalla, O. A. Müller and P. C. Scriba

Laboratorien für Klinische Chemie und Endokrinologie (Leiter Prof. Dr. P. C. Scriba), Medizinische Klinik Innenstadt der Universität München

(Received August 4, 1978)

Summary: This communication reports a method for increasing the speed of separation of bound and free antigen in radioimmunoassay systems with no loss in the specificity of binding. The technique uses a mixture of second antibody and polyethylene glycol. It is not species or antibody specific, and systems using specific first antibodies from rabbit, goat or sheep are all functional. Results for the assay of parathyrin, calcitonin and corticotropin are described here, al though the system has been shown to work for triiodothyronine, thyroxin, thyrotropin, thyroxine binding globulin and transferrin. The time taken for the reaction between first and second antibody is in the order of seconds, and the stability of the complex is unchanged over a period of hours.

\section{Eine schnelle und spezifische Methode zur Trennung von gebundenem und freiem Antigen in Radioimmunoassay- Systemen}

Zusammenfassung: Dieser Kurzbericht stellt eine Methode vor, die die Trennung von freiem und gebundenem Antigen in Radioimmunoassay-Systemen beschleunigt, ohne daß ein Verlust an Bindung oder Spezifität entsteht.

Bei dieser Technik wird eine Mischung von zweitem Antikörper und Polyethylenglykol eingesetzt und diese Technik funktioniert in Assay-Systemen, in denen ein spezifischer, erster Antikörper von Kaninchen, Ziege oder Schaf verwendet wird.

Es werden Ergebnisse für Parathyrin, Calcitonin und Corticotropin beschrieben. In folgenden weiteren Assays funktioniert diese Trennungsmethode ebenfalls: Triiodthyronin, Thyroxin, Thyreotropin, Thyroxin-bindendes Globulin und Transferrin. Die Zeit für die Reaktion zwischen erstem und zweitem Antikörper beträgt nur einige Sekunden und die Stabilität der Komplexe bleibt über mehrere Stunden erhalten.

\section{Introduction}

Many techniques for the separation of bound and free antigen have been described since the introduction of radioimmunoassay by Yalow \& Berson (1). Some of these are rapid, but relatively unspecific - for example polyethylene glycol, others are rapid, but time dependent, such as charcoal, and yet a third class is specific but time consuming, namely double antibody. Many variations on these themes have been practiced and this short communication presents yet another combination for separation of bound and free antigen - a mixture of polyethylene glycol and second antibody. This procedure can reduce the second antibody incubation time by over.
99\% and often only seconds are required for formation of the complex.

Assays are described for parathyrin, calcitonin and corticotropin, although in this laboratory the system works optimally for other radioimmunoassays, including triiodothyronine $\left(T_{3}\right)$, thyroxin $\left(T_{4}\right)$, thyrotropin, thyroxine binding globulin (TBG), transferrin and $\beta$ endorphine.

The first antibody species appears to be irrelevant and the three assays chosen for description use first antibodies raised in sheep, rabbit and goat. Comparison with polyethylene glycol and second antibody alone were carried out as controls. 


\section{Materials and Methods}

The antibodies used were as follows:

Parathyrin antibody S-478 VI from Dr. Hehrmann and Prof. Hesch, Hannover (2) is raised in a sheep.

Calcitonin antibody "Elfriede" from Prof. Ziegler, Ulm, is raised in a goat.

Corticotropin antibody from this laboratory was raised in a rabbit (3).

Second antibody was obtained from Wellcome and was either donkey-anti-rabbit or donkey-anti-sheep/goat.

The second antibody was used at a dilution of 1:20 (donkeyanti-rabbit) and at a dilution of 1:16 (donkey-anti-sheep/goat) Polyethylene glycol was obtained from Merck (Darmstadt) and had a $\mathrm{M}_{\mathrm{r}}$ of 6000 daltons.

\section{Assays}

A brief summary of the assay details is shown in table 1 . In all figures only maximum binding $\left(\mathrm{B}_{\mathrm{O}}\right.$ ) and unspecific binding are shown. In all assay systems the end-concentration of polyethylene glycol is $30 \mathrm{~g} / 1$. The assay for parathyrin has been described in detail elsewhere (4). The only alteration was the substitution of $100 \mu \mathrm{l}$ second antibody or $500 \mu \mathrm{l} 60 \mathrm{~g} / \mathrm{l}$ polyethylene glycol, alone or in combination, for the $1000 \mu \mathrm{l}$ $150 \mathrm{~g} / \mathrm{l}$ polyethylene glycol.

The assay for calcitonin has not been published but uses the same reagents as that for parathyrin (4), with the antibody dilution and incubation times shown in table 1 .

The assay for corticotropin has been published elsewhere (3) and the only addition is $500 \mu \mathrm{l} 60 \mathrm{~g} / \mathrm{l}$ polyethylene glycol to the second antibody.

\section{Results}

Figure 1 shows the kinetics for parathyrin, figure 2 for calcitonin and figure 3 for corticotropin. It is clear that in all systems, the maximal precipitation obtained with second antibody and polyethylene glycol occurs within seconds and remains stable for several hours, so that the time dependence factor is absent.

$60 \mathrm{~g} / \mathrm{l}$ polyethylene glycol alone had little or no effect ( $B_{o}$ and unspecific binding approximately equal), and

Tab. 1 .

\begin{tabular}{lccccccc}
\hline Assay & Serum & Buffer & $\begin{array}{l}\text { First } \\
\text { antibody }\end{array}$ & $\begin{array}{l}\text { Dilution } \\
\text { of first } \\
\text { antibody }\end{array}$ & Tracer $\left.{ }^{2}\right)$ & $\begin{array}{l}\text { Incubation Temperature } \\
\text { time }\end{array}$ \\
\hline & $(\mu l)$ & $(\mu l)$ & $(\mu l)$ & & $(\mu l)$ & $(h)$ & $\left({ }^{\circ} \mathrm{C}\right)$ \\
Parathyrin & 100 & 0 & 200 & $2400^{-1}$ & 100 & $18+6$ & 4 \\
Calcitonin & 100 & 0 & 100 & $10000^{-1}$ & 100 & $15+4$ & $4 /$ room \\
Corticotropin & $\left.0^{1}\right)$ & 300 & 100 & $30000^{-1}$ & 100 & $24+24$ & 4 temperature \\
\hline
\end{tabular}

1) Serum extracted, dried down and taken up in buffer.

2) Carrier $\gamma$-globulin added

Parathyrin - $20 \mathrm{mg} / \mathrm{l}$ (sheep)

Calcitonin $-70 \mathrm{mg} / \mathrm{l}$ (sheep)

Corticotropin $-70 \mathrm{mg} / \mathrm{l} \mathrm{rabbit)}$

${ }^{3}$ ) Time for preincubation and incubation with tracer (sequential saturation technique)

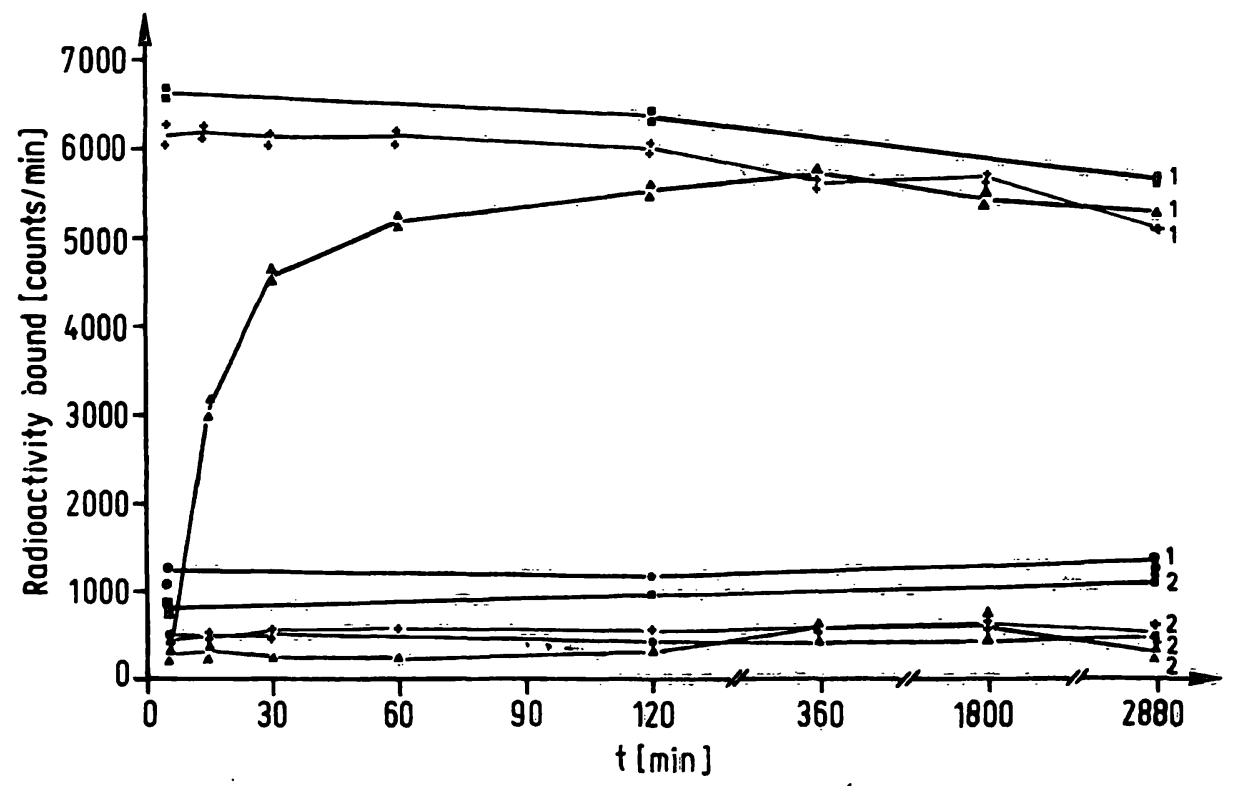

Fig. 1. Kinetics of the parathyrin assay. Separation of bound and free antigen using polyethylene glycol (concentration either $60 \mathrm{~g} / \mathrm{l}=\bullet-\longrightarrow$ or $150 \mathrm{~g} / \mathrm{l}=0-0)$ alone and in combination with second antibody $(60 \mathrm{~g} / \mathrm{l}$ polyethylene glycol) $(\Delta-\Delta \mathrm{i})$ and second antibody alone (^-4). All studies at $4{ }^{\circ} \mathrm{C}$ over a time period of $48 \mathrm{~h}$. $1=\mathrm{B}_{0}$

$2=$ unspecific binding 


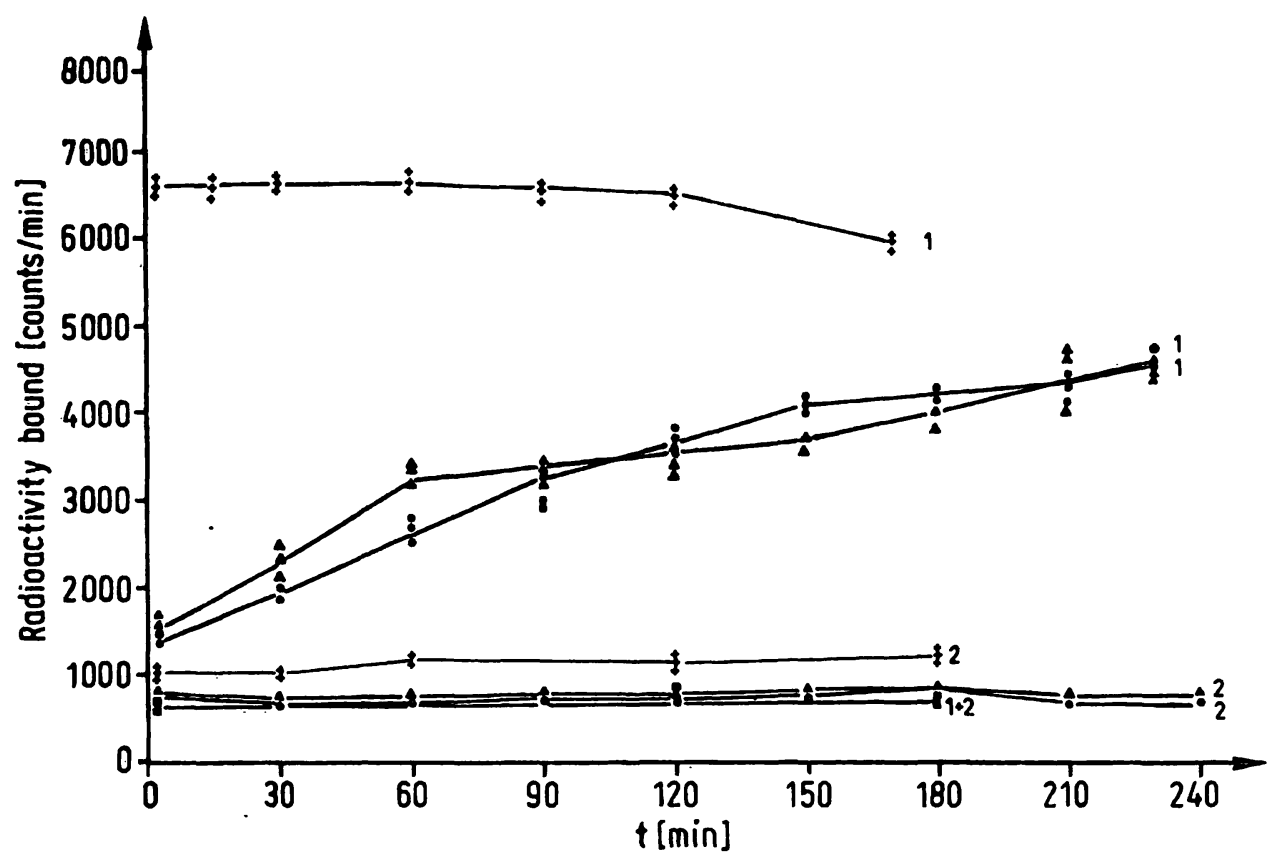

Fig. 2. Calcitonin assay: kinetics of the separation of bound and free antigen using polyethylene glycol $(60 \mathrm{~g} / \mathrm{l})$, polyethylene glycol and second antibody and second antibody alone. Second antibody was tested at both $4^{\circ} \mathrm{C}(\Lambda-\Delta)$, and room temperature $(\Delta--\Delta)$, and polyethylene glycol with $(\Delta-\Delta)$ and without $(\bullet-\bullet)$ second antibody at $4^{\circ} \mathrm{C}$ over either a 3 or $4 \mathrm{~h}$ period. $1=B_{0}$

$2=$ unspecific binding

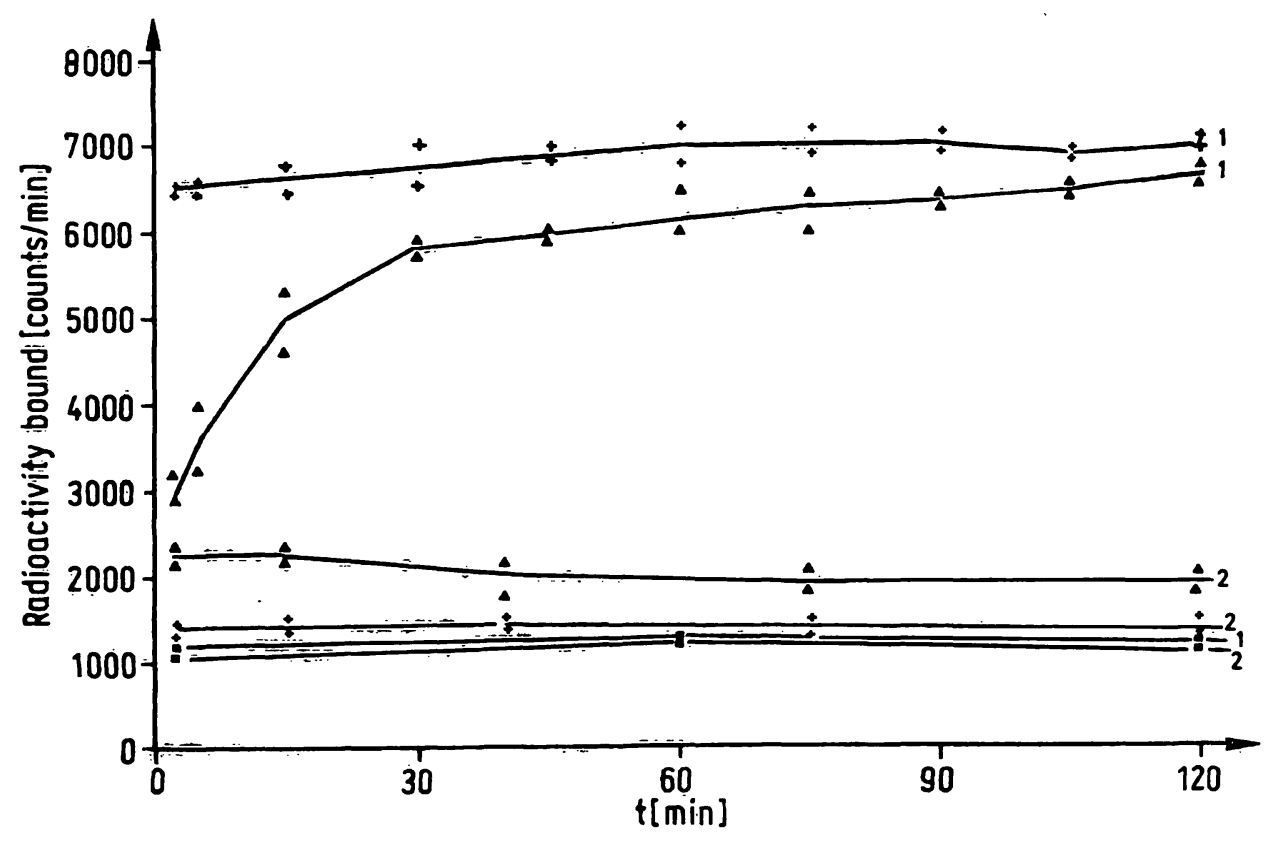

Fig. 3. Kinetics of the separation of bound and free antigen in the corticotropin assay. Polyethylene glycol $(60 \mathrm{~g} / \mathrm{l})$ alone $(\bullet-\bullet)$ and in combination with second antibody $(\Delta-\Delta)$; and second antibody alone $(\Delta-\Delta)$ were tested at $4^{\circ} \mathrm{C}$ over a $2 \mathrm{~h}$ period. $1=\mathbf{B}_{0}$

$2=$ unspecific binding 
second antibody alone showed much slower kinetics. The unspecific binding of the second antibody $+60 \mathrm{~g} / 1$ polyethylene glycol was much closer to second antibody than $150 \mathrm{~g} / \mathrm{l}$ polyethylene glycol, and the proteindependence of polyethylene glycol (4) was much reduced in the combined technique. The unspecific binding was under $3 \%$ in all cases using combined second antibody and polyethylene glycol.

\section{Discussion}

Although the use of second antibody and $60 \mathrm{~g} / \mathrm{l}$ polyethylene glycol is already used in some commercial radioimmunoassay kits (5) the technique employed is that the polyethylene glycol is given to the reaction mixture immediately before centrifugation, that is, after the second antibody has already reacted. The combined use of second antibody and polyethylene glycol is new and has the advantages of second antibody specificity and the speed of polythylene glycol or charcoal. For many assays the overnight incubation with second antibody can be reduced to minutes, thus saving time. Also second antibody with poor kinetics has been shown to be vastly improved with this combination separation.
The use of this technique in speeding up the first antibody reaction has given mixed results, giving quicker kinetics for thyrotropin and unchanged kinetics for parathyrin. These phenomena are under investigation.

The mode of action of this combined procedure probably lies in catalysis by the hydroxyl groups of polyethylene glycol of the rapid formation of precipitable first antibody to second antibody complexes, although this is probably not the whole story.

The results given in the parathyrin assay using this technique correlate well with published results (4). For the regression equation $y=a+b x, a=0.07, b=0.87$ and $r=0.89$ for 272 patient sera measured with both systems.

To conclude, this method, though simple, has the potential of speeding up all assays using second antibody separation without the loss of specificity or sensitivity. Moreover, the possibilities of adapting the technique for first antibody reactions are exciting enough to warrant further investigation.

\section{Acknowledgements}

The authors wish to thank Fräulein $C$ : Schuster, Fräulein C. Uhlig and Fräulein $C$. Wachter for technical assistance.

\section{References}

1. Yalow, R. \& Berson, S. (1960). J. Clin. Invest. 39, 1157 1175.

2. Hehrmann, R., Wilke, R., Nordmeyer, J. P. \& Hesch, R. D. (1976). Dtsch. Med. Wschr. 101, 1726-1729.

3. Müller, O. A., Fink, R., Baur, X., Ehbauer, M., Madler, M., \& Scriba, P. C. (1978). G.I.T. Labormedizin 2, 117-124.
4. Wood, W. G., Marschner, I., \& Scriba, P. C. (1978). Radioaktive Isotopen in Klinik und Forschung, 13. Band, Gasteiner Internationales Symposium (Höfer, R., ed.) Verlag H. Egermann, Wien, pp 479-488.

5. Diagnostic products corporation - Los Angeles, USA. RIA Kits for TSH, Digoxin, Cortisol, $\mathrm{T}_{3}, \mathrm{~T}_{4}$, Digitoxin, Gentamicin, Tobramycin and Amikacin.
Dr. W. G. Wood

Medizinische Klinik Innenstadt der Universität München Ziemssenstraße 1

D-8000 München 2 